\title{
Implementation of the Islamic Economics in the Traditional Market of Brebes Regency
}

\author{
Akbar Nuur Purnama Darma Wahana ${ }^{1^{*}}$, Muhammad Syaifulloh ${ }^{2}$ \\ ${ }^{I}$ Islamic economics, Postgraduate School of University Airlangga, Surabaya \\ ${ }^{2}$ Management of the faculty of economics and business Muhadi Setiabudi University, Brebes
}

\section{ARTICLE INFO}

AIJ use only:

Received date

Revised date

Accepted date

\section{Keywords:}

Islamic Economic

Traditional Market

\begin{abstract}
A B S T R A C T
The concept of Islamic Economics emphasizes that market Trading and pricing need to be regulated to uphold market balance and economic justice in view of interests of those involved in the market. This study aims to analyze the Islamic Economy's observance in accordance with Islamic sharia in the traditional markets, the number of merchant populations used as samples was 138 people, the research method uses qualitative descriptive, data collection techniques by observation and structured interviews.

The results showed that traders in the traditional market of Manis Kosambi Cikakak Village had practiced trade with Islamic Business Ethics. The Practice of Islamic Economy in the Traditional Market of Brebes Regency had been carried out by most traders almost $84.8 \%$. The system of commerce with the islamic economy is rooted in and habutual practices with islamic business ethics, doing bussiness by selling clean products, honesty, openness, fair, and by backing out of riba, or loan shark has been accustomed by traditional merchants of Brebes Regency in Manis Kosambi market Cikakak Village of Brebes Regency.
\end{abstract}

\section{INTRODUCTION}

It has become sunatullah that humans in their lives demand a variety of needs for survival, both in the form of food, clothing and shelter. To meet the demands of his life, humans are trying to produce, consume, market and distribute materials provided by nature.

(Indonesia, 2014) Trade is the order of activities related to transactions of domestic Goods and / or Services and goes beyond national

\footnotetext{
* Corresponding author.

E-mail address: slich@yahoo.com

Article with open access under license

borders for the purpose of transferring the rights to the Goods and / or Services to obtain compensation or compensation. (Fatah, 2012) The market is a means of meeting supply and demand between sellers and buyer. Islam requires market perfection that is free from the efforts of those who want market distortion in order to reap high profits in a short time. whereas (Arissandi, 2020) The product being bought must be Halal product in accordance with Islamic norms.

(Bangsawan, 2017) The role of religion in Indonesia has a very important role in social life. This is stated in the Pancasila as the ideology of the Indonesian nation's first precept "The Almighty God". The role of religion in connection with the development of human life, Djatmoko did not hesitate to say that religion is the main 
factor that plays a role in realizing the patterns of world perception for humans, these perceptions also influence the development of the world and the course of history. On the contrary history also implements changes and continual adjustments to these patterns of perception, especially in a rapidly changing society.

Islamic Economics is a term that is often used to describe an economic system based on the Qur'an and Hadith. Another name for Islamic economics is sharia economics. The term sharia economy is also inseparable from sources of sharia-based economic systems, namely the Qur'an and As Sunnah

Economic activities such as production, distribution, consumption, (Zaini \& MM, 2014) Import - export marketing are inseparable from the starting point of the Godhead and aim for God. If a Muslim works in the field of production or marketing then it is because he wants to fulfill the commands of Allah SWT

Indonesian people with the majority Muslim population and (Byarwati \& Sawarjuwono, 2013) Even though discourse on Islamic Economy has emerged since the 1970s, it must be admitted that the term Islamic Economics is still a "new item" in the discipline of Economics. The term Islamic Economics is still debated about whether or not it exists, whether Islam has an economic system or is it limited to normative rules. What is worrying is that the situation in the community as well as the Islamic community does not use the Islamic economic system in the process of commerce activities.

The existence of Islamic economics can be seen as a set of alternative economic principles that challenge the prevailing dominant economic system. One important dimension that needs to be understood first here is the principle of economics. In conventional economic systems, let's say the capitalistic economic system, the principle of economics is a knowledge. But in Islamic economics, economic principles are the product of knowledge whose sources are the Qur'an and Sunnah.

(Euis Amalia, 2015) For this reason, in Islamic economics the main pillar is the ethical and moral aspects of Islam itself. Every Muslim needs to behave in accordance with Islamic teachings and have homo islamicus behavior. That is, moral (akhlaq) Islam becomes the main handle of economic behavior that guides them to determine an activity is good or bad so it needs to be implemented or not. which is inseparable from the Islamic outlook on life. (Arifin \& Arifin, 2016) Because Islamic economic ethics is not fragmental but is an inseparable part of Islamic autonomy which is perfect.

In implementing Islamic economics in trade, the government also has a supervisory function. (Ulaan, Lusiana, \& Wahyudi, 2020) The government is responsible for realizing the welfare of its people. Creating a set of rules that can ensure the fulfillment of the needs of the whole community is a government obligation. (Fitri Amalia, 2014) In Islamic business ethics, surely every business actor must uphold Islamic business principles. According to Imam Ghazali quoted in Sofyan, there are several Islamic business principles: 1). If someone needs something, we must provide with a minimum profit. If necessary without profit. 2). If someone buys goods from the poor, the price is naturally exaggerated. 3). If there are people who are in debt and cannot afford to pay, then it is extended, not burdensome and should be released. 4). For those who have already bought, are not satisfied and want to return it, then it must be accepted again. 5). Debtors are encouraged to pay their debts more quickly. 6. If the sale is done with credit, then you should not force payment if the buyer is not capable.

\section{THEORY/CALCULATION (if any)}

Trading is the most common activity on the market. For this reason, the texts of the Qur'an in addition to providing imperative stimulation to trade, on the other hand also enlighten these activities with a number of signs or rules that can be applied in the market in an effort to uphold the interests of all parties, both individuals and groups.

In Islam, Muslims are encouraged to do anything as long as it is still in the corridor of sharia, meaning that as long as the effort does not violate the provisions in the will of Allah SWT. Likewise in the case of carrying out economic activities, everything can be done as long as it does not violate these rules. One of the economic activities can be seen in the market, where the seller and buyer meet to make transactions for goods or services, both in the form of production and price determination. Buying and selling transactions are permissible in Islam as long as it does not contain usury and things that can harm either party 
(Nadri, 2017) Islam recognizes the values of spiritualism in every material that is owned, which is central to the moral concept is that all items belong to Allah SWT. And how to conduct trade transactions in accordance with the rules of sharia. ]

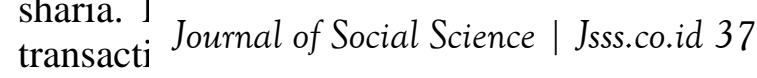
goods commodity as well as services can be traded in the Muslim market.

There are various transactions that are prohibited by the Messenger of Allah in normal market conditions, including the following: a) Tallaqi rukban, namely intercepting traders who bring goods from the production site before reaching the market. b) Deceptive trade, Islam strictly prohibits every forms of fraud. Included are classified as deceptive in trade are: 1) Ghisah, namely hiding defective goods sold and mixing ugly goods into good quality goods. 2) Tiffif, namely the actions of traders who reduce the scales and doses of an item being sold. c) Najasy trading, is pretending to offer high prices by accompanying the quality of the goods. With the aim of increasing the price of goods

In trading, a person is expected to sell his trade based on the principle of honesty in selling goods, the FIFO periodic system is used so that the goods that are sold earlier are sold earlier, and the latter goods, if the first item has not been sold due to a decrease in product quality, the selling price will be different, so buyers don't feel disadvantaged. (Syaifulloh, Wahid, \& Nasiruddin, 2018) Sales or returns are recorded on a card. In addition, recording purchases and sales will be more practical and can be used well for companies with low turnover.

(Zadjuli, 2007)Islam teaches that in fact the real human needs for primary, secondary and tertiary needs are limited. While the tools to meet human needs by utilizing science and technology is unlimited so that it will lead to partnerships among economic actors. What is not limited to humans is their lusts but their real purchasing power is still limited

Indicators of the Application of Islamic Economy in Brebes Traditional Market are: a. Fair competition, b. Honesty and openness d. Justice Principle d. Selling Halal Products.

\section{METHOD}

This type of research used in this study is a qualitative descriptive, respondents of this study were 138 Traders in the Traditional Market of Kosambi Manis, Cikakak Village, Banjarharjo District, Brebes Regency. The data used in this study are primary data and secondary data. (Utami \& Syaifulloh, 2019) Primary data were obtained through interviews with key informants and by distributing questionnaires to previously selected respondents. Secondary data obtained from data that has been recorded in institutions related to research, such as documents or archives as evidence of data presentation.

(Syaifulloh et al., 2018) The research stage is carried out by finding and formulating problems, compiling a theoretical framework, selecting data collection tools, analyzing data, and drawing conclusions. Methods of data collection by observation and interviews with respondents in this case to traders in the market.

\section{RESULTS AND DISCUSSION}

Based on the results of data collection through observation and interviews, the data found as follows:

Application of Islamic Economy in the Kosambi Sweet Market in Cikakak Village, Brebes

\begin{tabular}{llcc}
\multicolumn{4}{c}{ Regency } \\
\hline No & Indicator & Precentage & Amount \\
\hline 1 & Halal Products & $100 \%$ & 138 \\
\hline 2 & Fair Competition & $97 \%$ & 134 \\
\hline 3 & $\begin{array}{l}\text { Honesty and } \\
\text { Openness }\end{array}$ & $88 \%$ & 118 \\
\hline 4 & Justice & $64 \%$ & 75 \\
\hline 5 & $\begin{array}{l}\text { Not Borrowing } \\
\text { from Loan shark }\end{array}$ & $75 \%$ & 57 \\
\hline
\end{tabular}

Indicator 1 on selling halal products, it turns out that all traders have implemented selling halal products $100 \%$ from 138 traders, such as Halal Food in this case not found sellers of pork and pork, Clothing, illicit products (HP Bodong / Subhat Goods) and Pottery with looking for capital the lawful. (UNDANG-UNDANG REPUBLIK INDONESIA NOMOR 7 TAHUN 2014 TENTANG PERDAGANGAN, 2014) Because halal products are marketed to provide a sense of security and comfort in the community.

Indicator 2 on fair competition, a number of 134 traders or around 97\%. Usually business competition arises because they both sell the same product. Such as (Saman, 2010) Autonomy Principle, Principle of Honesty, Mutual Benefit 
Principle, Principle of Moral Integration, Trust and fulfillment of promises, mutual blessing, Not Hoarding, Not committing fraud and fraud.

Indicator 3 on regarding honesty and openness, about $88 \%$ of 138 traders or a number of 118 traders by way of (Fitri Amalia, 2014) being honest in running a business and being open when there are defects in goods and others.

Indicator 4 on a justice, there are about $64 \%$ or 75 traders in a business such as a situation or situation where everyone gets what they are entitled to. and there are Tera officers / Supervisors from the Government. (Amin, 2014) Harmony between the use of rights and their implementation based on the proposition of rights is an obligation: a. the right of each person large or small depends on large or small of the obligation. b. Under reasonable circumstances, it is not true that a person can obtain his rights not in harmony with

Indicator 5 on not borrowing from loan shark, there are 75 people or $75 \%$ of the traders (Ulum, 2016) Prohibition of Muslims to collect multiple usury, hand over a number of assets to others by attracting a certain additional amounts every month, while the amount of loan is still intact.

\section{CONCLUSION}

A conclusion contains the main points of the article. It should not replicate the abstract, but might elaborate the significant results, possible applications and extensions of the work. The conclusion of the research is presented briefly, narrative, non-bulleted, and conceptual. The research impact must be stated.

\section{REFERENCES}

1. Amalia, Euis. (2015). Mekanisme Pasar dalam Kebijakan Penetapan Harga Adil dalam Perspektif Ekonomi Islam. Al-Iqtishad: Journal of Islamic Economics, 5(1). https://doi.org/10.15408/aiq.v5i1.2106

2. Amalia, Fitri. (2014). Etika Bisnis Islam: Konsep dan Implementasi pada Pelaku Usaha Kecil. AlIqtishad: Jurnal Ilmu Ekonomi Syariah, 6(1), 133-142.

3. Amin, Mahir. (2014). Konsep Keadilan Dalam Perspektif Filsafat Hukum Islam. Al-Daulah: Jurnal Hukum Dan Perundangan Islam, 4(02), 322-343.

4. Arifin, M. Nur, \& Arifin, M. Nur. (2016). Pemikiran Ekonomi Koperasi Mohammad Hatta: Relevansinya dengan Etika Ekonomi Islam. Laksita Indonesia.
5. Arissandi, Muhamad Rifa'i. (2020). Implementasi Undang-Undang Republik Indonesia Nomor 33 Tahun 2014 tentang Jaminan Produk Halal (Studi Kasus Produk Makanan dan Minuman di Bintang Swalayan Ponorogo). IAIN Ponorogo.

6. Bangsawan, Moh Indra. (2017). Eksistensi Ekonomi Islam (Studi Tentang Perkembangan Perbankan Syariah di Indonesia). Law and Justice, 2(1), 24-34.

7. Byarwati, Anis, \& Sawarjuwono, Tjiptohadi. (2013). Ekonomi Islam atau Iqtishad? Imanensi: Jurnal Ekonomi, Manajemen, Dan Akuntansi Islam, 1(1), 14-24.

8. Fatah, Dede Abdul. (2012). Monopoli dalam Perspektif Ekonomi Islam. Al-Iqtishad: Jurnal Ilmu Ekonomi Syariah, 4(2).

9. Indonesia, Pemerintah Republik. (2014). Undang-Undang Republik Indonesia Nomor 5 Tahun 2014 tentang Aparatur Sipil Negara.

10. Nadri, Ikhwan. (2017). Strategi Pemasaran UMKM di Sanggr Peni dalam Perpektif Ekonomi Islam.

11. Saman, Muhammad. (2010). Persaingan industri PT. Pancanata Centralindo perspektif etika bisnis dalam islam.

12. Syaifulloh, Muhammad, Wahid, Farhan Saefudin, \& Nasiruddin, Nasiruddin. (2018). Analisis Produktivitas Kegiatan Penelitian Dosen di Universitas Muhadi Setiabudi. JBIMA (Jurnal Bisnis Dan Manajemen), 6(2), 154-162.

13. Ulaan, Gedeon Firnandus, Lusiana, Nur Aisyah, \& Wahyudi, Kalvin Edo. (2020). IMPLEMENTASI NILAI KESADARAN BERBANGSA DAN BERNEGARA DI UNIT KEGIATAN MAHASISWA UNIVERSITAS PEMBANGUNAN NASIONAL "VETERAN" JAWA TIMUR. Syntax, 2(6), 57.

14. Ulum, Khozainul. (2016). Hakikat keharaman riba dalam islam. JES (Jurnal Ekonomi Syariah), l(1).

15. UNDANG-UNDANG REPUBLIK INDONESIA $\begin{array}{lllll}\text { NOMOR } & 7 & \text { TAHUN } & 2014 & \text { TENTANG }\end{array}$ PERDAGANGAN. (2014).

16. Utami, Suci Nur, \& Syaifulloh, M. (2019). Comparative And Competitive Advantage Agribusiness Of Jawa Brebes Cattle (Jabres) In Brebes Regency. Journal of Agri SocioEconomics and Business, 1(1), 15-24.

17. Zadjuli, Suroso Imam. (2007). Reformasi Ilmu Pengetahuan dan Pembangunan Masyarakat Madani di Indonesia. Journal of Islamic Business 
and Economics, 1(1), 29-52.

18. Zaini, Ahmad Afan, \& MM, M. Pd. (2014).

Journal of Social Science | Jsss.co.id 39
Pasar Persaingan Sempurna dalam Perspektif Ekonomi Islam. Jurnal Ummul Qura, IV (2). 